\title{
MANDATORY CORPORATE SOCIAL AND ENVIRONMENTAL RESPONSIBILITIES \\ IN THE NEW INDONESIAN LIMITED LIABILITY LAW
}

\author{
Yu Un Oppusunggu 1
}

\begin{abstract}
On 16 August 2007 President Susilo Bambang Yudhoyono signed the Bill of Limited Liability Company, as approved by the Parliament, and consequently it became the Law No. 40 of Year 2007 regarding Limited Liability Company. The law revokes the then existing Law No. 1 of Year 1995. This Law has 14 chapters and 161 articles, and introduces new provision on, inter alia, corporate social and environmental responsibilites (CSER). The legislators have specifically dedicated Chapter $V$ and its Article 74 to this effect. CSER is defined as commitment of the Company to participate in sustainable economic development with the intention of increasing the living quality and beneficial environment for the Company itself, the surrounding communities, and public in general. This article discusses CSER as stipulated in the Law in relation the logic of a limited liability company. It analyzes the necessity of stipulating it in the Law in relation to the objective of a limited liability company.
\end{abstract}

\section{Introduction}

16 August 2007 marked a new milestone for the legislation of limited liability companies in Indonesia. On that day, President Susilo Bambang Yudhoyono signed the Bill of Limited Liability Company, as approved by the Parliament (Dewan Perwakilan Rakyat), as the Limited Liability Company Law. The new law is registered as the Law No. 40 of the Year 2007 regarding Limited Liability Company. ${ }^{2}$ This law is to annul and void the then existing Limited Liability Company Law, the Law No. 1 of the Year $1995,{ }^{3}$ the first-ever Indonesian legislation on limited liability companies. ${ }^{4}$ The new

${ }^{1}$ Lecturer for Interlegal Law (Hukum Antar Tata Hukum) courses, member of the International Law Division, the Faculty of Law of the University of Indonesia. The writer would like to thank the late Associate Professor Th. Sardjito and Professor Agus Sardjono for their inputs in the writing of this article, however, opinion and analysis herein is the author's. The author welcomes all comments at yu_oppu@ui.ac.id.

2 Undang-Undang No. 40 Tahun 2007 tentang Perseroan Terbatas, LNRI (State Gazette of the Republic Indonesia) 2007 No. 106, TLNRI (Supplement of the State Gazette of Republic Indonesia) No. 4756.

${ }^{3}$ Undang-Undang No. 1 Tahun 1995 tentang Perseroan Terbatas, LNRI 1995 No. 13, TLNRI No. 3587. However, if the Company Law 2007 fails to regulate any issue that was covered by the Company Law 1995, the latter according to article 159 of Law 2007 continues to exist.

4 Prior to the enactment of this law, the limited liability companies were regulated by the Commercial Code (Wetboek van Koophandel voor Indonesië (Stb. 1847-23)) of the colonial era. 
law shall be referred to as the "2007 Company Law", whereas the latter as the "1995 Company Law" herein.

The government, in accordance with article 5 (1) of the 1945 Constitution, on 12 October 2005 proposed the 2007 Company Law bill to the Parliament. According to the First Amendment to the Constitution, the power to legislate a law rests upon the Parliament. ${ }^{5}$ The reason to enact a new law on limited liability companies was to refine the 1995 Company Law so that the role of limited liability companies in economic development could be accelerated and to provide the sound basis for the private sector to respond to the progress of globalization. ${ }^{6}$

The 2007 Company Law consists of 161 articles, divided into 14 chapters; whereas the 1995 Company Law had 129 articles, divided into 12 chapters. The two new chapters introduced in the 2007 Company Law are Chapter V on Corporate Social and Environmental Responsibilities (CSER), and Chapter XI on Cost. The latter is concerned with any cost borne inter alia as result of approval for corporate name, legalizing the status of legal entity for the company, and approval for amending companies' articles of association. ${ }^{7}$ This issue used to be stipulated in implementing regulations, such as Government Regulation (Peraturan Pemerintah) or Ministerial Decree (Keputusan Menteri), of the 1995 Company Law. The former, on the other hand, is a completely new stipulation, which states that any limited liability company having its industry in and/or related to natural resources has to take up corporate social and environmental responsibilities. ${ }^{8}$ The CSER, as stipulated by article 74 (2), are corporate obligations in monetary terms that have to be budgeted and accounted as corporate cost.

This article discusses these new responsibilities, and how they fit, or unfit, to the logic of a limited liability company in Indonesia. In this article, I use the term corporation, company (perseroan), and limited liability company (perseroan terbatas or PT) interchangeably. Whenever it fits to the context of its related legislation, I use NV (naamloze vennootschap), its Dutch counterpart.

Even though it is relevant to make reference and discussion to the Environmental Law, ${ }^{9}$ especially on obligation to ecological preservation, I decided to concentrate on the company aspects of the issue at hand.

\section{A Brief History of Company Law in Indonesia}

The Indonesian legal system inherited the concept of a limited liability company from the Dutch. The Dutch term for a limited liability company is Naamloze Vennootschap, or nameless company. The term "nameless" is so employed due to the

\footnotetext{
${ }^{5}$ See article 20 (1) of the Constitution (First Amendment).

${ }^{6}$ See Explanatory Note of the President of the Republic of Indonesia on the Bill of Limited Liability Company (Keterangan Presiden Republik Indonesia mengenai Rancangan Undang-Undang tentang Perseroan Terbatas), pp. 2-3. Available online at www.legalitas.org.

${ }^{7}$ See article 153 of Law 2007.

8 See article 74 (1) of Law 2007: "Perseroan yang menjalankan kegiatan usahanya di bidang dan/atau berkaitan dengan sumber daya alam wajib melaksanakan Tanggung Jawab Sosial dan Lingkungan.

9 Undang-Undang No. 23 Tahun 1997 tentang Pengelolaan Lingkungan Hidup (Law on the Environment Management), LNRI 1997 No. 68, TLNRI No. 3699. This Law was revised and thus revoked by Undang-Undang No. 32 Tahun 2007 tentang Perlindungan dan Pengelolaan Lingkungan Hidup (Law on the Environmental Protection and Management), LNRI No. 2009 No.140, TLNRI No. 5059.
} 
fact that the company runs its business not on behalf of its shareholders but to pursue its own ends. ${ }^{10}$ Therefore it must not use the name(s) of its shareholders, but must have its own name. ${ }^{11}$ The Commercial Code initially was promulgated as the commercial code for the European population group in the Netherlands Indië, the predecessor of the Republic of Indonesia. ${ }^{12}$ As commercial needs required the Europeans to engaged more intensely, mostly, with the Chinese of the Foreign Orientals Group, the Netherlands Indië government later expanded the Commercial Code to include the Foreign Orientals population. ${ }^{13}$ For the native-Indonesians, the Netherlands Indië government specially designed and promulgated Indonesische Maatschappij op Aandelen (IMA), a native Indonesian version of limited liability companies, in 1939.14 Basically there was not much difference between a limited liability company of Commercial Code and that of IMA, other than for the latter e.g. only native-Indonesians could be its shareholders, and all shares had to be bearer shares (saham atas nama). ${ }^{15}$ For some unclear reasons, IMA was not popular and rarely used by Indonesians as their business vehicle. ${ }^{16}$

The Commercial Code was a code of commercial law. It did not regulate only $\mathrm{NV}$, but also other types of business associations, i.e. partnerships, maatschap, firma, limited partnership (commanditaire vennootschap), ${ }^{17}$ and maritime law. In total it had 754 articles, and dedicated only 21 articles for regulating NV. It was hardly sufficient to regulate all issues related to limited liability companies. Therefore in practice, for things that were not regulated or insufficiently regulated in the Commercial Code, the Indonesian law would refer to the Commercial Code of the Netherlands, which had 120 articles, as guidelines. ${ }^{18}$ It is easy to conclude that such a brief regulation was hardly compatible with the necessities of development. After the Independence, when population groups based on racial distinction had lost its relevance and therefore

${ }^{10}$ Article 36 para. 1 of the "Commercial Code" reads "De naamloze vennootschap heeft geene firma, noch draagt den naam van een' of meer der vennooten, maar zij ontleent hare benaming alleen van het voorwerp van haar bedrijf." This stipulation is translated by R. Subekti and R. Tjitrodusibio as "Perseroan terbatas tak mempunyai sesuatu firma, dan tak memakai nama salah seorang atau lebih dari para peseronya namun diambilnyalah nama perseroan itu dari tujuan perusahaannya semata-mata."

11 R. Soekardono, Hukum Dagang Indonesia, Jilid I (Bagian Kedua), Jakarta: Rajawali, 1991, pp. 118120.

12 The Dutch classified, or rather divided, the population in the Netherlands Indië into three population groups, i.e. the Europeans, the Foreign Orientals, and the Native Indonesians. This division was stipulated in article 163 of Indische Staatsregeling (IS), a kind of constitution for the the Netherlands Indië. The Europeans were subject to Dutch laws, the Foreign Orientals were also mostly subject to Dutch laws, and the Native Indonesians were left under adat law. See Sudargo Gautama and Robert Hornick, An Introduction to Indonesian Law, Bandung: Alumni, 1983, pp. 1-21.

${ }^{13}$ See Sudargo Gautama, Pembaharuan Hukum di Indonesia, Jakarta: Keng Po, 1956, p. 10.

14 Ordonnatie op de Indonesisch Maatschappij op Aandeelen, Stb. 1939-569 jo. 7170.

15 For short description of IMA see R. Rochmat Soemitro, Penuntun Perseroan Terbatas (Naamloze Vennootschap), Bandung: Eresco, 1959, p. 16. See also Nono A. Makarim, Mengada-ada tentang Perseroan Terbatas, a manuscript, Jakarta: Pusat Studi Hukum dan Ekonomi Fakultas Hukum Universitas Indonesia, s.a., pp. 8-9.

${ }^{16}$ It may seem that the form of IMA is incompatible with international commerce. See Makarim, p.

17 For description in English for these business associations see Charles Himawan and Mochtar Kusumaatmadja, Business Law: Contracts and Business Associations, Bandung: Lembaga Penelitian Hukum dan Kriminologi Fakultas Hukum Universitas Padjadjaran, 1972, pp. 21-39.

18 R. Rochmat Soemitro, Penuntun Perseroan Terbatas (Naamloze Vennootschap), Bandung: Eresco, 1959, p. 1. 
naturally ceased to exist, it has been the communis opinio doctorum that the need of commercial law in the modern era would be best suited by the codes of law previously used only for the Europeans. The use of NV had been increasing significantly. There was no clear reason, however, why Indonesians abandoned the idea of IMA, and preferred the form of PT. ${ }^{19}$ One could guess, however, that PT of Commercial Code allowed foreigners to take shareholding and thus it welcomed foreign capitals. The shift of policy on foreign capital showed that PT was the type of business association instructed in the 1967 Foreign Investment Law. ${ }^{20}$

The 1967 Foreign Investment Law triggered law reform, or adjustments in economic law, to modernize Indonesian law to best serve the foreign needs. ${ }^{21}$ For that purpose, a survey of Indonesian economic law was imminent. ${ }^{22}$ To some extent, the survey was continued by Economic Law and Improved Procurement System (ELIPS) Project, which was a law reform effort jointly launched by the Government of Indonesia, the USAID, and the Faculty of Law of the University of Indonesia. The result of ELIPS Project on limited liability companies was the 1995 Company Law. The law, it was said, had private-law oriented and facilitative company law. ${ }^{23}$ At this point, it is obvious that the 1995 Company Law had its process and development as a reaction to modern needs and reform.

\section{The Concept of Limited Liability Company}

The legal concept of a PT is that the liabilities of the shareholders are limited up to their shareholding. The concept of PT has three organs, i.e. the General Meeting of the Shareholders (GMS), the board of directors, and the board of commissioners. ${ }^{24}$ The board of directors receives a mandate from the GMS to run and operate the company and act on behalf of the company to any third party. ${ }^{25}$ The board of commissioners, on the other hand, is to supervise the board of directors in running and operating the company, and to report to the GMS. ${ }^{26}$ The latter is the supreme organ of a PT, which has all the power that has not been delegated to the other two organs. ${ }^{27}$ This separation of power creates the so-called corporate veil.

\footnotetext{
19 The name NV at this point onward has been translated into PT, but the source of law remained the Commercial Code.

20 Undang-Undang Penanaman Modal Asing No. 1 Tahun 1967, LNRI No. 1 Year 1967, TLNRI No. 2818. See Sudargo Gautama, Komentar atas Undang-Undang Perseroan Terbatas (Baru) Tahun 1995 No. 1 Perbandingan dengan Peraturan Lama, Bandung: Citra Aditya Bakti, 1995, pp. 1-2.

21 See International Legal Center, Minutes of Meeting on Indonesian Legal Development, NY, 1 July 1970, in Dr. Sumantoro, Bunga Rampai Permasalahan Penanaman Modal dan Pasar Modal/Problems of Investment in Equities and in Securities, Jakarta: Bina Cipta, 1984, pp. 437-444.

22 Other than the survey carried out by Himawan and Kusumaatmadja above, it also covered Mining Law, Labor Law and Social Legislation, Taxation, and Agrarian Law.

${ }^{23}$ See Normin S. Pakpahan, Introduction to the New Company Law on Indonesia: An Overview of Law Number 1 of the Year 1995 on Limited Liability Companies, Jakarta: ELIPS Project, Office of Coordinating Minister for Economic, Finance and Development Control, 1995, pp. 1-10.

${ }^{24}$ Article 1 point 2 of the 2007 Company Law.

${ }^{25}$ Articles 92-107 of the 2007 Company Law.

${ }^{26}$ Articles $108-121$ of the 2007 Company Law.

${ }^{27}$ Articles 75-91 of the 2007 Company Law.
} 
The board of directors runs and operates the company for the interest of the company and in accordance with its purpose and objective. ${ }^{28}$ In doing so, the board of directors has to apply the policy they deem correct (kebijakan yang dipandang tepat), which is defined as policy that, among others, is based on dexterity, available opportunity, and usual practice in the same business sector. ${ }^{29}$ The objective and purpose of the company are stated in its articles of association (Anggaran Dasar), which are formulated and amended when necessary by its shareholders.

The NVs of the Commercial Code were intended to pursue its own business objective. This can be concluded from the name of the NV, which should reflect its business objective. ${ }^{30}$ The 1995 Company Law regulated that the activities of the company has to be in line with its purpose and objective, and should not violate the law, public order and/or morality. ${ }^{31}$ The 2007 Company Law also regulates the same with slight refinement in structuring the wordings. Since a PT is a profit-generating business association, it will be obvious that its interest is none other than to generate profit as much as possible.

\section{PT is a Legal Entity}

The Commercial Code was not firm in giving NV the status as a legal person (rechtspersoon, badan hukum). No article in the Commercial Code explicitly states that it was a legal person. However, in practice NV was perceived and treated as a legal person by making reference to article 40 paragraph 2,32 which states that the shareholders are not responsible beyond their shares. ${ }^{33}$ The 1995 Company Law, on the contrary, gave this status unequivocally. In the definition of a PT, it immediately gave its status of legal entity. ${ }^{34}$ The same approach is maintained by the 2007 Company Law. ${ }^{35}$

${ }^{28}$ Article 92 (1) of the 2007 Company Law.

${ }^{29}$ Article 92 (2) of the 2007 Company Law and elucidation of this article reads "Yang dimaksud dengan "kebijakan yang dipandang tepat" adalah kebijakan yang, antara lain didasarkan pada keahlian, peluang yang tersedia, dan kelaziman dalam dunia usaha yang sejenis."

${ }^{30}$ Article 40 para. 2 of the Commercial Code, "De vennooten of houders dier actien of aandeelen zijn niet verder aansprakelijk dan voor het volle beloop derzelve." "Perseroan terbatas tak mempunyai sesuatu firma, dan tak memakai nama salah seorang atau lebih dari para peseronya namun diambilnyalah nama perseroan itu dari tujuan perusahaannya semata-mata." As translated by Subekti and Tjitrosudibio. Underlined is mine.

31 Article 2 of the 1995 Company Law reads "Kegiatan perseroan harus sesuai dengan maksud dan tujuannya serta tidak bertentangan dengan peraturan perundang-undangan, ketertiban umum, dan/atau kesusilaan."

32 R. Soekardono, Hukum Dagang Indonesia, Jilid I (Bagian Kedua), Jakarta: Rajawali, 1991, p. 121.

33 "De vennooten of houders dier actien of aandeelen zijn niet verder aansprakelijk dan voor het volle beloop derzelve." "Para pesero atau pemegang saham atau andil tersebut tidak bertanggungjawab untuk lebih daripada jumlah penuh andil-andil itu."

${ }^{34}$ Article 1 point 1 of the 1995 Company Law, as translated by Normin S. Pakpahan in Introduction to the New Company Law of Indonesia: An Overview of Law Number I of the Year 1995 on Limited Liability Company, Jakarta: ELIPS Project, 1995, “A Limited Liability Company hereinafter referred to as the Company means a legal entity established based on an agreement, conducting business activities with all of its authorized capital divided into shares, and fulfilling the requirements stipulated in this Law and its implementing regulations". "Perseroan Terbatas yang selanjutnya disebut perseroan adalah badan hukum yang didirikan berdasarkan perjanjian, melakukan kegiatan usaha dengan modal dasar yang seluruhnya 
It is generally acknowledged that a legal entity has its own legal personality before the law, separated from its shareholders and operators. The law acknowledges it as a bearer of rights and obligations like a natural person. It can have its own wealth, and generate wealth. As a law-created entity, it is run or operated by its board of directors, in the case of a PT, to meet the purpose and objective of its existence.

The 2007 Company Law defines PT as a legal entity, which is an association of capital, established based on an agreement, conducts its activities with authorized capital as regulated in this Law and its implementing regulations. ${ }^{36}$ This definition clearly puts emphasis on PT as an association of capital, which was not included in the definition previously provided by the 1995 Company Law. It is also an emphasis on the objective, purpose, and interest of PT in generating and maximizing profit. Therefore, all resources must be directed to that pursuit.

\section{CSER of the 2007 Company Law}

One of the novel stipulations of the 2007 Company Law is the obligations of companies toward its surroundings. Generally it is known as the corporate social responsibility. The 2007 Company Law however moves further by adding environmental responsibility to companies. Elucidation of article 74 (1) says that CSER is to constantly create a relationship that is harmonious, equal, and compatible with the environment, values, norms, and culture between the company and the surrounding community. ${ }^{37}$ The companies that have to perform CSER are companies that have its business activity in natural resources or its business activities have effects on natural resources utilities. In fulfilling this obligation, companies have to make CSER budget. ${ }^{38}$ It is however unclear how much money has to be allocated. It is also not explained how much money has to be allocated for the social responsibility and for the environmental responsibility. The only guidance provided by the 2007 Company Law is that in making such budget, companies have to consider fairness (kepatutan) and suitability (kewajaran). Companies that do not perform their CSER are subject to be various sanctions according to relevant regulations. ${ }^{39}$ The 2007

terbagi dalam saham, dan memenuhi persyaratan yang ditetapkan dalam Undang-undang ini serta peraturan pelaksanaannya".

${ }^{35}$ Article 1 point 1 of the 2007 Company Law.

36 Article 1 point 1 of the 2007 Company Law. "Perseroan Terbatas, yang selanjutnya disebut Perseroan, adalah badan hukum yang merupakan persekutuan modal, didirikan berdasarkan perjanjian, melakukan kegiatan usaha dengan modal dasar yang ditetapkan dalam Undang-Undang ini serta peraturan pelaksanaannya."

37 "Ketentuan ini bertujuan untuk tetap menciptakan hubungan Perseroan yang serasi, seimbang, dan sesuai dengan lingkungan, nilai, norma, dan budaya masyarakat setempat. Yang dimaksud dengan "Perseroan yang menjalankan kegiatan usahanya di bidang sumber daya alam" adalah Perseroan yang kegiatan usahanya mengelola dan memanfaatkan sumber daya alam. Yang dimaksud dengan "Perseroan yang menjalankan kegiatan usahanya yang berkaitan dengan sumber daya alam" adalah Perseroan yang tidak mengelola dan tidak memanfaatkan sumber daya alam, tetapi kegiatan usahanya berdampak pada fungsi kemampuan sumber daya alam."

38 Article 74 (2) of the 2007 Company Law reads "Tanggung Jawab Sosial dan Lingkungan sebagaimana dimaksud dalam ayat (1) merupakan kewajiban Perseroan yang dianggarkan dan diperhitungkan sebagai biaya Perseroan yang pelaksanaannya dilakukan dengan kepatutan dan kewajaran."

${ }^{39}$ Article 74 (3) of the 2007 Company Law reads "Perseroan yang tidak melaksanakan kewajiban sebagaimana dimaksud pada ayat (1) dikenai sanksi sesuai dengan ketentuan peraturan perundangundangan." 
Company Law itself does not specify what kind of sanctions will be given for noncompliance. Therefore, one has to refer to positive laws that deal with natural resources, such as Oil and Gas Law, ${ }^{40}$ Water Resources Law, ${ }^{41}$ Forestry Law, ${ }^{42}$ or Environmental Law. ${ }^{43}$ However, since CSER is a newly conceptualized obligation it is unsurprising that these laws have no stipulation to enforce its execution nor penalize companies for failing to comply with the obligations of corporate social and environmental responsibilities. At this junction it may safe to conclude that this obligation is not yet practicable until an implementing regulation, in the form of a Government Regulation, is promulgated by the government. ${ }^{44}$

\section{Is CSER in Line with the Interest of PT?}

As put it above a PT has to be run to pursue its purpose and objective. The Board of directors must always put first the interest of the PT in fulfilling their agency duties. It is no doubt that PT is a capitalistic concept of business association. That being said, what is the relevance of CSER for a PT?

For the last several decades, it has been a corporate credo to pay attention to the PT's surroundings. Many PTs are competing to execute their corporate social responsibility. As Balkan has argued, it is only moral for a corporation to launch a corporate social responsibility program, from a good health care program for its employees to active participation in community development, if it will be in its interest. Its interests are the interests of its shareholders, i.e. wealth maximizing program. ${ }^{45}$ Accordingly, the Board of directors will be launching immoral program, from the perspective of a corporation and its shareholders, if it ends up in programs that fail to generate and maximize profit for the corporation, or to increase the corporation's shareholders value. Therefore a CSER has to be carefully calculated in order to best serve the interests of the PT and its shareholders. When economically it will not result in profit-maximizing outcomes, then it is conceptually right and fit not to launch any CSER.

By legally requiring PTs to have CSER, then what used to be the domain of private sector to self-govern its social participation to development has become a mandatory participation. From the perspective and logic of a PT, this stipulation may be unnecessary too much, and also excessive. This obligation by itself clearly disregards any economic calculation that presupposes its existence. Thus even though, for instance, it is neither economically efficient nor beneficial to launch a CSER program, a PT has no alternative but to comply with the 2007 Company Law. Consequently it may hinder the maximum increase of shareholder value and set aside the interest PT and of its shareholders. Why then such stipulation has to be made in

${ }^{40}$ Undang-Undang No. 22 Tahun 2001 tentang Minyak dan Gas Bumi, LNRI 2001 No. 136, TLNRI No. 4152.

41 Undang-Undang No. 7 Tahun 2004 tentang Sumber Daya Air, LNRI 2004 No. 32, TLNRI No. 4377.

42 Undang-Undang No. 41 Tahun 1999 tentang Kehutanan, LNRI 1999 No. 167, TLNRI No. 3888, jo. Undang-Undang No. 19 Tahun 2004.

43 Undang-Undang No. 32 Tahun 2009 tentangPerlindungan dan Pengelolaan Lingkungan Hidup.

${ }^{44}$ Article 74 (4) of the 2007 Company Law.

45 See Joel Bakan, The Corporation: The Pathological Pursuit of Profit and Power, NY: Free Press, 2004 , pp. 34-35. 
the Company Law? Isn't it more appropriate, for instance, to stipulate it in the Environmental Law or in a law that specifically deals with natural resources?

\section{PT as a Member of the Society}

It has been mentioned above that PT is a legal entity, a legal subject (subyek hukum). Therefore, in the context of Indonesia, its society and legal system, legal subjects consist of individual (pribadi kodrati/natuurlijk persoon), legal person (pribadi hukum/rechtspersoon), and official (ambtenaar/pejabat). ${ }^{46}$ Every legal subject has obligations toward other legal subjects and the society in general. With respect to the environment, it is stipulated that every person - which is defined to include individual and legal person ${ }^{47}$ - has the rights of good and healthy environment, as well as the obligation to preserve the environment. ${ }^{48}$ Accordingly, a PT is to preserve the environment, especially the one whose business deals with natural resources or business activities related to natural resources. At this point it is clear that although a PT is a capitalistic legal concept when it has been transplanted and operated in the Indonesian legal system, it loses its pure-form and embraces a sociological function as a member of the society.

\section{PT in the Context of Familial Principle}

Indonesia was established not on the basis of capitalism, but on the basis of a common endeavor based on familial principles (asas kekeluargaan). Consequently, the economy is to be structured as a common endeavor based on familial principle, ${ }^{49}$ and that the organization of the national economy shall be based on economic democracy that upholds the principles of solidarity, efficiency along with fairness, sustainability, keeping the environment in perspective, self-sufficiency, and that is concerned as well with balanced progress and with the unity of the national economy. ${ }^{50}$ The two discussed laws, the Company Law 2007 and the Environmental Law, are constructed under article 33 of the Constitution.

Thus the legal construction of PT cannot be deemed as purely capitalistic anymore. It has been adjusted to fit in the Indonesian context by the adoption of the familial principle. It is interesting to note that the concept of NV was not as capitalistic as it should be. The Commercial Code stipulated a shareholder had limited number of six votes, if the total shares of the NV were more than one hundred shares, or of three votes, if the total shares were less than one hundred shares. ${ }^{51}$ Thus it was not "one-

${ }^{46}$ Soerjono Soekanto and Purnadi Purbaçaraka, Sendi-sendi Ilmu Hukum dan Tata Hukum, Bandung: Citra Aditya Bakti, 1993, p. 41.

47 Article 1 point 32 of the Protection and Environment Management Law. "Setiap orang adalah orang perseorangan atau badan usaha, baik yang berbadan hukum maupun yang tidak berbadan hukum."

${ }^{48}$ Article 65 (1) of the Protection and Environment Management Law, "Setiap orang berhak atas lingkungan hidup yang baik dan sehat sebagai bagian dari hak asasi manusia"; and article 67 of the Protection and Environment Management Law, "Setiap orang berkewajiban memelihara kelestarian fungsi lingkungan hidup serta mengendalikan pencemaran dan/atau kerusakan lingkungan hidup."

${ }^{49}$ Article 33 (1) of the Constitution.

${ }^{50}$ Article 33 (4) of the Constitution.

${ }^{51}$ Article 54 para. 4 of the Commercial Code. 
share-one-vote" mechanism. The voting right, however, was changed into a purely capitalistic mechanism of "one-share-one-vote" by article 72 (1) of the 1995 Company Law, ${ }^{52}$ and is maintained by article 84 (1) of the 2007 Company Law. This right of the shareholders is limited by the obligation of a PT as a member of the society in pursuing its purpose and objective.

This article 74 has survived a judicial review after the Constitutional Court ruled that it does not violate the Constitution and stated it consistent with Indonesia's economic concept. 53

\section{Conclusion}

It is generally accepted that the concept of PT has its roots in capitalism. Its purpose and objective are to generate profit and to serve the interests of its shareholders. However, given the role of PT as a legal entity in the context of Indonesia and its legal system, it has obligations toward other legal subjects and the society. Thus, one of its obligations is to preserve the environment.

In this perspective the stipulation of the 2007 Company Law on CSER is neither excessive nor unsuitable. By making CSER as obligation, the 2007 Company Law has put legal obligation to PTs as legal subjects and disregard any economic calculation of CSER to the PTs' benefits.

\section{Bibliographies}

Bakan, Joel. The Corporation: The Pathological Pursuit of Profit and Power. NY: Free Press, 2004.

Constitutional Court, Decision No. 53/PUU-VI/2008.

Himawan, Charles and Mochtar Kusumaatmadja, Business Law: Contracts and Business Associations, Bandung: Lembaga Penelitian Hukum dan Kriminologi Fakultas Hukum Universitas Padjadjaran, 1972.

Indonesia. Undang-Undang Dasar Republik Indonesia 1945. . Undang-Undang Penanaman Modal Asing No. 1 Tahun 1967. LNRI No. 1 Tahun 1967, TLNRI No. 2818.

. Undang-Undang No. 1 Tahun 1995 tentang Perseroan Terbatas. LNRI 1995 No. 13, TLNRI No. 3587.

. Undang-Undang No. 23 Tahun 1997 tentang Pengelolaan Lingkungan Hidup. LNRI 1997 No. 68, TLNRI No. 3699.

Undang-Undang No. 41 Tahun 1999 tentang Kehutanan. LNRI 1999 No. 167, TLNRI No. 3888.

. Undang-Undang No. 22 Tahun 2001 tentang Minyak dan Gas Bumi. LNRI 2001 No. 136, TLNRI No. 4152.

.Undang-Undang No. 7 Tahun 2004 tentang Sumber Daya Air. LNRI 2004 No. 32, TLNRI No. 4377.

52 Article 72 (1) of the 1995 Company Law reads "Unless otherwise stipulated in the Articles of Association, each issued share carriers a right to one vote."

53 See Decision No. 53/PUU-VI/2008 of the Constitutional Court. 
. Undang-Undang No. 40 Tahun 2007 tentang Perseroan Terbatas. LNRI 2007 No. 106, TLNRI No. 4756.

. Undang-Undang No. 32 Tahun 2009 tentang Perlindungan Pengelolaan Lingkungan Hidup. LNRI 2009 No. 140, TLNRI No. 5059.

- Keterangan Presiden Republik Indonesia mengenai Rancangan Undang-Undang tentang Perseroan Terbatas. Jakarta: s.a. Available online at www.legalitas.org.

Netherlands Indies. Wetboek van Koophandel voor Indonesië. Stb. 1847-23. . Indonesische Staatsregeling. Stb `855-2.

. Ordonnatie op de Indonesisch Maatschappij op Aandeelen. Stb. 1939-569 jo. 7170.

Gautama, Sudargo. Pembaharuan Hukum di Indonesia, Jakarta: Keng Po, 1956.

. Komentar atas Undang-Undang Perseroan Terbatas (Baru) Tahun 1995 No. 1 Perbandingan dengan Peraturan Lama, Bandung: Citra Aditya Bakti, 1995.

Gautama, Sudargo and Robert Hornick. An Introduction to Indonesian Law. Bandung: Alumni, 1983.

Makarim, Nono A. Mengada-ada tentang Perseroan Terbatas, a manuscript, Jakarta: Pusat Studi Hukum dan Ekonomi Fakultas Hukum Universitas Indonesia, s.a.

Pakpahan, Normin S. Introduction to the New Company Law on Indonesia: An Overview of Law Number 1 of the Year 1995 on Limited Liability Companies. Jakarta: ELIPS Project, Office of Coordinating Minister for Economic, Finance and Development Control, 1995.

Soekanto, Soerjono and Purnadi Purbaçaraka. Sendi-sendi Ilmu Hukum dan Tata Hukum. Bandung: Citra Aditya Bakti, 1993.

Soekardono, R. Hukum Dagang Indonesia, Jilid I (Bagian Kedua). Jakarta: Rajawali, 1991.

Sumantoro. Bunga Rampai Permasalahan Penanaman Modal dan Pasar Modal/Problems of Investment in Equities and in Securities. Jakarta: Bina Cipta, 1984.

Soemitro, R. Rochmat. Penuntun Perseroan Terbatas (Naamloze Vennootschap). Bandung: Eresco, 1959. 